\begin{tabular}{|c|c|}
\hline Title & $\begin{array}{l}\text { A novel heterozygous IT GB3 p.T 720del inducing spontaneous activation of integrin a IIb } \beta \text { 3 in autosomal dominant } \\
\text { macrothrombocy topenia with aggregation dy sfunction }\end{array}$ \\
\hline Author(s) & $\begin{array}{l}\text { Miy ashita, Naohiro; Onozawa, Masahiro; Hay asaka, Koji; Y amada, Takahiro; Migita, Ohsuke; Hata, Kenichiro; Okada, } \\
\text { Kohei; Goto, Hideki; Nakagawa, Masao; Hashimoto, Daigo; Kahata, Kaoru; Kondo, Takeshi; Kunishima, Shinji; } \\
\text { Teshima, Takanori }\end{array}$ \\
\hline Citation & $\begin{array}{l}\text { A nnals of hematology, } 97(4), 629-640 \\
\text { https://doi.org/10.1007/300277-017-3214-4 }\end{array}$ \\
\hline Issue Date & 201804 \\
\hline Doc URL & http:/hdl.handle.net/2115/3417 \\
\hline Rights & The final publication is avail able at link.springer.com \\
\hline Type & article (author version) \\
\hline File Information & A OHE-D-17-00597_R2-3.pdf \\
\hline
\end{tabular}

Instructions for use 
Title

\title{
A novel heterozygous ITGB3 p.T720del inducing spontaneous activation of integrin $\alpha I I b \beta 3$ in autosomal dominant macrothrombocytopenia with aggregation dysfunction
}

\author{
Authors \\ Naohiro Miyashita ${ }^{1}$, Masahiro Onozawa $^{1}$, Koji Hayasaka $^{2}$, Takahiro Yamada $^{3}$, Ohsuke Migita $^{4}$, \\ Kenichiro Hata ${ }^{4}$, Kohei Okada ${ }^{1}$, Hideki Goto ${ }^{1}$, Masao Nakagawa ${ }^{1}$, Daigo Hashimoto ${ }^{1}$, Kaoru Kahata ${ }^{1}$, \\ Takeshi Kondo $^{1}$, Shinji Kunishima ${ }^{5}$, Takanori Teshima ${ }^{1}$ \\ ${ }^{1}$ Deparatment of Hematology, Hokkaido University Faculty of Medicine, Graduate School of Medicine, \\ Sapporo, Japan \\ ${ }^{2}$ Division of Laboratory and Transfusion Medicine, Hokkaido University Hospital, Sapporo, Japan \\ ${ }^{3}$ Division of Clinical Genetics, Hokkaido University Hospital, Sapporo, Japan \\ ${ }^{4}$ Department of Maternal-Fetal Biology, National Research Institute for Child Health and Development, \\ Tokyo, Japan \\ ${ }^{5}$ Department of Advanced Diagnosis, Clinical Research Center, National Hospital Organization Nagoya \\ Medical Center, Nagoya, Japan
}




\section{Corresponding author}

Masahiro Onozawa, MD, PhD

Department of Hematology, Hokkaido University Faculty of Medicine, Graduate School of Medicine,

Sapporo, Japan

Kita 15, Nishi 7, Kita-ku, Sapporo, JAPAN 0608638

Phone: +81-11-706-7214

Fax: +81-11-706-7823 
1

2

\section{Acknowledgments}

We thank Professor Kazuhiko Matsuno (Rakuno Gakuen University, Ebetsu) for kind advice for flow

cytometry.

\section{Funding}

There is no financial relationship with other people or organizations that could inappropriately influence

their work.

\section{Disclosure of conflict of interest}

The authors declare that they have no conflict of interest. 


\section{Abstract}

We identified a novel heterozygous ITGB3 p.T720del mutation in a pedigree with

macrothrombocytopenia exhibiting aggregation dysfunction. Platelet aggregation induced by ADP and

collagen was significantly reduced, while ristocetin aggregation was normal. Integrin $\alpha \mathrm{IIb} \beta 3$ was partially

activated in a resting status, but platelet expression of $\alpha \mathrm{IIb} \beta 3$ was downregulated. Functional analysis

using a cell line showed spontaneous phosphorylation of FAK in $\alpha \mathrm{IIb} / \beta 3$ (p.T720del)-transfected $293 \mathrm{~T}$

cells in suspension conditions. Abnormal cytoplasmic protrusions, membrane ruffling, and cytoplasmic localization of $\alpha \mathrm{IIb} \beta 3$ were observed in $\alpha \mathrm{IIb} / \beta 3$ (p.T720del)-transfected CHO cells. Such morphological changes were reversed by treatment with an FAK inhibitor. These findings imply spontaneous, but partial, activation of $\alpha \mathrm{IIb} \beta 3$ followed by phosphorylation of FAK as the initial mechanism of abnormal thrombopoiesis. Internalization and decreased surface expression of $\alpha \operatorname{IIb} \beta 3$ would contribute to aggregation dysfunction. We reviewed the literature of congenital macrothrombocytopenia associated with heterozygous $I T G A 2 B$ or $I T G B 3$ mutations. Reported mutations were highly clustered at the membrane proximal region of $\alpha \mathrm{IIb} \beta 3$, which affected the critical interaction between $\alpha \mathrm{IIb}$ R995 and $\beta 3$ D723, resulting in a constitutionally active form of the $\alpha \mathrm{IIb} \beta 3$ complex. Macrothrombocytopenia caused by a heterozygous activating mutation of $I T G A 2 B$ or $I T G B 3$ at the membrane proximal region forms a distinct entity of rare congenital thrombocytopenia. 


\section{Keywords}

Congenital macrothrombocytopenia, FAK phosphorylation, ITGB3, integrin $\alpha \operatorname{IIb} \beta 3$, platelet

\section{Introduction}

Congenital macrothrombocytopenia is a group of rare platelet disorders characterized by a decreased

platelet count with macrothrombocytes showing a varied bleeding tendency. Mutations causing

congenital macrothrombocytopenia have been reported in more than 12 genes including $M Y H 9$, which is

responsible for autosomal dominant $M Y H 9$ disorders, and GPIBA, GPIBB and GP9, which are

responsible for Bernard-Soulier syndrome [1-4]. Variants of integrin $\alpha I I b$, coded by $I T G A 2 B$, and integrin

$\beta 3$, coded by ITGB3, have also been identified in patients with congenital macrothrombocytopenia [5-12].

The integrin $\alpha \operatorname{IIb} \beta 3$ complex is expressed on the surface of platelets and megakaryocytes. $\alpha \operatorname{IIb} \beta 3$ plays

essential roles in the processes of platelet aggregation, thrombus formation, and thrombopoiesis through

actin remodeling [13-15]. These reported variants are associated with spontaneous, but partial, activation

of $\alpha \operatorname{IIb} \beta 3$ and macrothrombocytopenia with aggregation dysfunction of platelets. The molecular

consequences after spontaneous $\alpha \operatorname{IIb} \beta 3$ activation contributing to macrothrombocytopenia and

aggregation dysfunction have not been fully elucidated. Here, we report a novel heterozygous ITGB3

p.T720del variatnt in a pedigree of macrothrombocytopenia and its causative mecahnisms. We reviewed 
the literature and illustrated the distinct clinical entity of this rare congenital macrothrombocytopenia with

platelet aggregation dysfunction.

\section{Materials and Methods}

\section{Patients}

The patients were a 56-year-old Japanese woman (i2 in Fig 1A) and her two sons (ii2 and ii3 in Fig

1A). They had no bleeding tendencies and near-normal bleeding time evaluated by Duke's method (Table

1). Hematological examination revealed mildly decreased platelet counts $\left(58-75 \times 10^{9} / \mathrm{L}\right)$ with an increase of mean platelet volume (13.4-14.5 fl, Table 1$)$.

Written informed consent was obtained from all family members in accordance with the Declaration of Helsinki. This study was approved by the Institutional Review Board of Hokkaido University Faculty of Medicine.

Genetic analysis

Genomic DNA was obtained from the three affected family members (i2, ii2, and ii3 in Fig 1A) and a non-affected member (ii1 in Fig 1A) in the pedigree. Whole exome sequencing (WES) was performed by HiSeq1500/2500 (Illumina, San Diego, CA) using SureSelect - Human ALL ExomeV6 (Agilent Technologies, Santa Clara, CA). The ITGB3 gene was amplified using the primer set 5'- 
CTCCTGCTTCTTCACAACC-3' and 5'-GGTCTGAGACTCTTAAGTGGAAG-3'. The identified

ITGB3 p.T720del variatnt was confirmed by direct sequencing using the primer 5'-

\section{CTCCTGCTTCTTCACAACC-3'}

\section{Structural analysis}

Interaction between $\alpha \mathrm{IIb}$ and $\beta 3$ molecules was evaluated by in silico model construction using

SWISS-MODEL and Cn3D 4.3.1. [16,17].

\section{Platelet glycoprotein analysis}

Surface expression of $\alpha \mathrm{IIb}, \beta 3$, $\alpha \mathrm{IIb} \beta 3$, and GPIb was evaluated by mean fluorescent intensity (MFI) of

CD41 (5B12; Dako, Glostrup, Denmark), CD61 (SZ21; Beckman-Coulter, Fullerton, CA), CD41 (P2;

Beckman-Coulter, Fullerton, CA), and CD42b (AN51; Dako, Glostrup, Denmark), respectively.

The activation status of $\alpha \operatorname{IIb} \beta 3$ was evaluated by binding of the ligand-mimetic antibody PAC-1 (BD

Biosciences, Franklin Lakes, NJ) with or without $1 \mathrm{mM}$ of an Arg-Gly-Asp-Ser (RGDS) mimetic

antagonist (Sigma-Aldrich, St. Louis, MO) [18]. Platelets were discriminated from other blood cells by

GPIb staining. MFI ratio was calculated by dividing MFI of PAC-1 binding on platelets by that of PAC-1

binding in the presence of the RGDS mimetic antagonist. MFI ratio was also calculated by dividing MFI

of PAC-1 binding on platelets in the presence of $1 \mu \mathrm{M}$ adenosine diphosphate (ADP) by MFI of PAC-1 
binding in the absence of ADP. Activation index is defined as $\left(F_{\mathrm{x}}-F_{\min }\right) /\left(F_{\max }-F_{\min }\right) . F_{\mathrm{x}}$ is the MFI of

PAC-1 binding to the platelets, $F_{\min }$ is the MFI of PAC-1 binding in the presence of the RGDS mimetic antagonist, and $F_{\max }$ is the MFI of PAC-1 binding in the presence of $200 \mathrm{mM}$ phorbol-12-myristate-13-

acetate (PMA; Wako, Osaka, Japan).

The activation state of platelets was evaluated by expression of P-selectin, which was measured by the binding of anti-human CD62P antibody (AK-4; BD Pharmingen, Franklin Lakes, NJ) in the presence or absence of $1 \mu \mathrm{M}$ ADP. Platelets were discriminated from other blood cells by $\beta 3$ staining.

To examine total expression levels of $\alpha \mathrm{IIb} \beta 3$ in platelets including the cytoplasmic pool, Western blotting was performed using platelet-rich plasma (PRP) lysed with SDS lysis buffer containing $1.7 \%$ SDS, 60 mM Tris-HCl, pH 6.8, 0.85\% 2-mercaptoethanol, and proteinase inhibitor cocktail (Roche, Basel, Switzerland). $\alpha \operatorname{IIb} \beta 3$ was detected with anti-integrin $\beta 3$ antibody (AB2984, Millipore, Bedford, MA), and protein loading of each well was controlled by anti-GAPDH antibody (V-18, Santa Cruz Biotechnology, Santa Cruz, CA). Platelet specific protein fraction was determined by anti- $\beta 1$ tubulin antibody (PD033, Medical \& Biological Laboratories, Nagoya, Japan) [19].

Cloning, mutagenesis, and transfection assay

ITGA2B and ITGB3 cDNAs were amplified from a normal individual's platelet cDNA and cloned into pcDNA3.1 (Invitrogen, Carlsbad, CA). ITGB3 p.D723H and ITGB3 p.T720del were introduced to 
pcDNA3.1/ITGB3 using a site-directed mutagenesis kit (Agilent Technologies, Santa Clara, CA). ITGB3

p.D723H was a functionally proven variant previously reported as a cause for macrothrombocytopenia

resembling our cases [6].

The pcDNA3.1/ITGA2B and pcDNA3.1/ITGB3 or its mutant were transiently transfected into 293T

cells or Chinese hamster ovary $(\mathrm{CHO})$ cells by Lipofectamine ${ }^{\mathbb{B}} 3000$ Reagent (Thermo Fisher

Scientific, Waltham, MA). Transfected 293T cells were washed with phosphate-buffered saline and lysed

with $1 \%$ Triton $\mathrm{X}-100,1 \mathrm{mM}$ sodium vanadate, and proteinase inhibitor cocktail to examine tyrosine

phosphorylation of focal adhesion kinase (FAK) by Western blotting. Integrin $\alpha$ IIb and integrin $\beta 3$

were detected with anti-integrin $\alpha$ IIb antibody (B-9, Santa Cruz Biotechnology, Santa Cruz, CA) and

anti-integrin $\beta 3$ antibody, respectively. FAK and tyrosine-phosphorylated FAK were detected with anti-

FAK antibody (EP695Y; Abcam, Cambridge, UK) and anti-phospho-FAK (Tyr397) antibody (3283, Cell

Signaling, Danvers, MA), respectively. Protein loading of each well was assessed by anti-GAPDH

antibody. CHO cells cotransfected with pcDNA3.1/ITGA2B and pcDNA3.1/ITGB3 or its mutant were

subjected to an adhesion assay to examine morphological changes. Twenty-four hours after transfection,

the cells were seeded onto a $100 \mu \mathrm{g} / \mathrm{ml}$ fibrinogen-coated glass-based dish (IWAKI, Chiba, Japan). After

2-hour incubation at $37^{\circ} \mathrm{C}$, the cells were fixed with $3 \%$ paraformaldehyde and permeabilized with $0.1 \%$

Triton-X-100. CHO cells were stained with AB2984 and Hoechst 33342 (Dojindo Laboratories,

Kumamoto, Japan) followed by Alexa 594-conjugated secondary antibody (Thermo Fisher Scientific, 
Waltham, MA) staining. Images were obtained using a Keyence BZ-X700 all-in-one fluorescence

microscope (Keyence, Osaka, Japan). Morphological changes were defined as either rhomboidal changes, abnormal cytoplasmic protrusions, or membrane ruffling. One hundred cells were counted to calculate the percentage of cells with morphological changes.

For the FAK inhibitor assay, transfected 293T and CHO cells were cultured in Dulbecco's modified Eagle's medium with $10 \%$ fetal bovine serum and $1 \%$ penicillin/streptomycin and in Roswell Park Memorial Institute 1640 medium with $10 \%$ fetal bovine serum and 1\% penicillin/streptomycin, respectively, with or without FAK Inhibitor 14 (1,2,4,5-Benzenetetraamine tetrahydrochloride (Y15), Sigma-Aldrich, St. Louis, MO). After 24-hour incubation at $37^{\circ} \mathrm{C}$ with $5 \% \mathrm{CO}_{2}$, transfected cells were reseeded and tyrosine phosphorylation of FAK and morphological changes were evaluated by Western blotting and immunofluorescence staining, respectively.

\section{Statistical analysis}

Total expression levels of $\beta 3$ in the patient's (i2) platelets and those in the control's platelets, levels of tyrosine phosphorylation of FAK in $293 \mathrm{~T}$ cells transfected with wild-type or mutated $\alpha \mathrm{IIb} / \beta 3$ vectors, and rate of morphological changes in $\mathrm{CHO}$ cells transfected with wild-type or mutated $\alpha \mathrm{IIb} / \beta 3$ vectors were compared by the t-test. $P$-values $<0.05$ were considered as a statistical significance. 


\section{Results}

Pedigree of a family with congenital macrothrombocytopenia

In all affected family members, giant platelets were observed in a peripheral blood smear (Fig 1B).

Platelet aggregation induced by ADP $(10 \mu \mathrm{mol} / \mathrm{l})$ and collagen $(2 \mu \mathrm{g} / \mathrm{ml})$ was obviously reduced, though platelet aggregation induced by ristocetin $(1.5 \mathrm{mg} / \mathrm{ml})$ was within the normal limit (Table 1 , Fig $1 \mathrm{C})$. The pedigree of the family indicates that the inheritance pattern is autosomal dominant (Fig 1A). Congenital diseases exhibiting macrothrombocytopenia, including MYH9 disorders, Bernard-Soulier syndrome, and type 2B von Willebrand disease, were excluded by aggregation dysfunction of platelets in response to ADP and collagen, normal expression levels of GPIb $\alpha$ (Table 1) and the inheritance pattern, and normal activity of von Willebrand factor (data not shown), respectively.

Identification of ITGB3 p.T720del variant

A total of 1526 gene alterations were detected by WES in the three affected members but not in a nonaffected member. Then, gene alterations without exonic and splice site variants and synonymous variants were excluded. As a result, 128 non-synonymous or non-frameshift gene alterations remained. Among them, a novel in-frame heterozygous 3-bp deletion (ITGB3, c.2236_2238delACC) resulting in the loss of Thr720 (p.T720del) (Human Genome Variation Society nomenclature for the mature protein) was identified. Direct sequence analysis revealed that all of the three affected family members had ITGB3 
p.T720del variant as a heterozygous variant (Fig 1D). ITGB3 p.T720del variant resulted in one threonine

loss at the submembrane domain of integrin $\beta 3$.

In silico analysis of the interaction between $\alpha \mathrm{IIb}$ and $\beta 3$ molecules revealed that ITGB3 p.T720del

induces conformational alteration of the $\alpha \mathrm{IIb} \beta 3$ complex (Fig 1E). ITGB3 p.T720del variant causes a one amino acid shift downstream, thereafter, resulting in a change from $\beta 3$-D723 to $\beta 3-R 723$. The positively charged $\alpha$ IIb-R995 faces the negatively charged $\beta 3$-D723 in wild-type $\alpha I I b \beta 3$, while the positively charged $\alpha$ IIb-R995 faces the positively charged $\beta 3$-R723 in $\alpha I I b \beta 3$ with ITGB3 p.T720del. This subtle change expands the distance between the $\alpha \mathrm{IIb}-\mathrm{R} 995$ and $\beta 3-723$ positions, like previously reported ITGB3 p.D723H [6], in which the positively charged $\alpha \mathrm{IIb}-\mathrm{R} 995$ faces the positively charged $\beta 3-\mathrm{H} 723$ in $\alpha \operatorname{IIb} \beta 3$ with ITGB3 p.D723H.

Decreased surface expression and sponatenous partial activation of $\alpha I$ IIb $\beta 3$

Flow cytometry was performed to evaluate the expression levels of integrin molecules on the surface of platelets. Surface expression levels of $\alpha \mathrm{IIb}, \beta 3$, and $\alpha \mathrm{IIb} \beta 3$ on platelets of patient i2 were decreased in comparison with the levels in the control, not only in resting conditions but also in response to ADP and PMA (Table 2). However, Western blotting using the lysate from PRP revealed that there were no significant differences in tota relativet expression levels of integrin $\beta 3$ compared to $\beta 1$-tubulin between the affected member and the control (Fig 2A), suggesting that the marked reduction in surface expression 
of $\alpha \operatorname{IIb} \beta 3$ was due to cytoplasmic retention of $\alpha \operatorname{IIb} \beta 3$. Relative expression of integrin $\beta 3$ compared to

\section{GAPDH was decreased in an affected member reflecting thrombocytopenia (Fig 2A). PAC-1 is an}

antibody that recognizes an epitope exposed on the activated form of the $\alpha \operatorname{IIb} \beta 3$ complex. Spontaneous

PAC-1 binding to the resting patient's (i2) platelets was detected, and $\alpha \operatorname{IIb} \beta 3$ was more activated in the patient's (i2) platelets than in the control's platelets (Fig 2B). Activation status of $\alpha \operatorname{IIb} \beta 3$ was evaluated by the activation index, which was higher in the patient's platelets (Fig $2 \mathrm{C}$ ). On the other hand, $\alpha \operatorname{IIb} \beta 3$ was less activated in response to ADP in the patient (i2) (Fig 2D). MFI of anti-CD62P binding to resting platelets in the patient (i2) was equal to that in the control, but that in response to ADP was lower in the patient (i2) than in the control (Fig 2E). These findings suggested that $\alpha \operatorname{IIb} \beta 3$ of the affected family member was spontaneously and partially activated.

p.T720del causes spontaneous phosphorylation of FAK.

FAK is a tyrosine kinase that physically interacts with $\alpha \mathrm{IIb} \beta 3$, and phosphorylation of the molecule transduces $\alpha$ IIb $\beta 3$ outside-in signaling to downstream [20,21]. Phosphorylated FAK promotes cell proliferation and affects cell mobility via actin remodeling [22]. Physiologically, FAK is phosphorylated in adhesion cells, but phosphorylation is cancelled in suspension cells. To evaluate FAK phosphorylation, expression vectors of ITGA2B and wild-type or mutated ITGB3 were transfected to a cell line. In 293T cells cotransfected with $I T G A 2 B$ and $I T G B 3$ expression vectors, expression of transfected $\alpha \mathrm{IIb}$ and $\beta 3$ 
was verified (Fig 3A). One day after transfection, the cells were re-seeded and incubated for one hour.

Cells from the suspension fraction and adhered fraction were separately collected for Western blotting.

FAK in $\alpha \mathrm{IIb} / \beta 3$ (p.D723H)-expressing cells and that in $\alpha \mathrm{IIb} / \beta 3$ (p.T720del)-expressing cells were highly

phosphorylated with significant differences even under suspension conditions (t-test, $P=0.025$ vs. WT and

$P=0.013$ vs. WT, respectively), although there was no significant difference between them in the adhered

conditions (Fig 3B).

Mutated $\beta 3$ causes morphological changes that can be reversed by an FAK inhibitor.

CHO cells expressing $\alpha \mathrm{IIb} / \beta 3$ (p.D723H) or $\alpha \mathrm{IIb} / \beta 3$ (p.T720del) showed rhomboidal changes,

abnormal cytoplasmic protrusions, and membrane ruffling (Fig 3C). Immunofluorescence staining using

anti- $\beta 3$ antibody showed membrane localization of $\alpha \mathrm{IIb} \beta 3$ in wild-type $\alpha \mathrm{IIb} / \beta 3$-expressing cells and

cytoplasmic localization in $\alpha \mathrm{IIb} / \beta 3$ (p.T720del)-expressing cells and $\alpha \mathrm{IIb} / \beta 3$ (p.D723H)-expressing cells

(Fig 3C, right). Few cells with morphological changes were observed in wild-type $\alpha \mathrm{IIb} / \beta 3$-expressing

CHO cells, but significantly increased numbers of cells with morphological changes were observed in

$\alpha \mathrm{IIb} / \beta 3$ (p.T720del) or (p.D723H)-expressing cells (Fig 3D). We treated the cells with an FAK inhibitor

to determine whether these morphological changes observed in mutated $\beta 3$-transfected cells are caused by

FAK phosphorylation. FAK Inhibitor 14 is a selective FAK inhibitor that displays no significant activity

for a range of other kinases including PDGFR, EGFR, and IGF-IR. FAK Inhibitor 14 has been shown to 
prevent FAK autophosphorylation at the putative activation site, tyrosine 397 [23]. The effect of the FAK

inhibitor was verified using $293 \mathrm{~T}$ cells. FAK Inhibitor 14 hindered tyrosine phosphorylation of FAK in a dose-dependent manner (Fig 3E). The FAK inhibitor reversed the morphological changes observed in mutated $\beta 3$-transfected cells in a dose-dependent manner in CHO cells (Fig 3F).

\section{Discussion}

Dysfunction pattern of platelet aggregation in our patients resembles that of Glanzmann thrombasthenia (GT). GT is caused by a homozygous mutation on ITGA2B or ITGB3, resulting in a loss or reduced level of $\alpha \mathrm{IIb} \beta 3$. These mutations causing GT mostly occur in the extracellular domain of integrin [24] and are considered to be loss-of-function mutations. Previously, autosomal dominant macrothrombocytopenia was reported in cases with membrane proximal region variants of either ITGA2B or ITGB3 (Table 3). So far, 4 variants of ITGA2B (p.G991C, p.F993del, p.R995W, p.R995Q) and 3 variants of ITGB3 (p.L718P, p.D723H, p.L718del) have been reported [12,6,8,10,9,11]. Variants of each gene are highly clustered in a small region, amino acids $991-995$ for $I T G A 2 B$ and $718-723$ for ITGB3 (Table 3). All reported cases showed giant platelets, mild thrombocytopenia and decreased surface expression of $\alpha \operatorname{IIb} \beta 3$ on platelets with only mild or no clinical bleeding tendency. All of the cases had a heterozygous integrin variant same as our cases. These cases are considered to have the same mechanisms by which their clinical characteristics developed. Three variants of ITGA2B (p.F993del, p.G991C, 
p.R995W) were shown to cause constitutive phosphorylation of FAK $[9,10]$. We verified the ITGB3

membrane proximal cytoplasmic tail variant confers constitutive activation of $\alpha \operatorname{IIb} \beta 3$ and phosphorylation

of FAK, as do ITGA2B variants.

We confirmed spontaneous but partial $\alpha \mathrm{IIb} \beta 3$ activation using the patient's (i2) platelets. In a

physiological state, inside-out signaling induces a change in $\alpha \mathrm{IIb} \beta 3$ from an inactive bent form to an

extended and activated form by stimulation of agonists such as ADP, collagen, and thromboxane A2 [25-

28]. A salt bridge between $\alpha$ IIb R995 and $\beta 3$ D723 is an essential interaction to maintain an activation-

constraining clasp [29]. However, as shown in Fig 1E, the deletion of threonine (T720) unclasps the

highly conserved membrane proximal complex of $\alpha \mathrm{IIb}$ and $\beta 3$ cytoplasmic tails and constitutes the

extended form even in resting conditions (Fig 4). Spontaneous $\alpha \mathrm{IIb} \beta 3$ activation leads to tyrosine

phosphorylation of FAK via constitutive outside-in signaling, which results in abnormal actin remodeling in megakaryocytes, leading to abnormal regulation of proplatelet formation [30,31]. The abnormal actin remodeling is associated with a decreased number and increased size of proplatelet tips, leading to macrothrombocytopenia $[6,10]$. Thus, the variants around the juxtamembrane region of either $\alpha \mathrm{IIb}$ or $\beta 3$ work as gain-of-function variants. Morphological changes in $\alpha \mathrm{IIb} / \beta 3$ (p.T720del)-expressing CHO cells support these possible mechanisms (Fig 3C). For the first time, we showed that an FAK inhibitor hindered the morphological changes induced by ITGB3 p.T720del and p.D723H variant. This finding strongly suggests that the FAK signaling directly contributes to the morphological change of transfected 
cells. Megakaryocytes extend long cytoplasmic projections called proplatelets, and the tips of the

proplatelets are released as platelets [32]. The RhoA-ROCK-myosin-IIA pathway suppressed proplatelet formation in premature megakaryocytes [33,34]. Partially activated $\alpha \operatorname{IIb} \beta 3$ decreased RhoA activity and induced proplatelet-like protrusion in CHO cells [35]. Phosphorylated FAK would cause macrothrombocytopenia via RhoA suppression (Fig 4)

Surface expression levels of $\alpha \operatorname{IIb} \beta 3$ were decreased on the patient's platelets, though the total expression level of $\beta 3$ in patient i2 was the same as that in the control. This observation suggested that ITGB3 p.T720del induces the localization change of $\alpha \mathrm{IIb} \beta 3$. Immunofluorescence staining of transfected $\mathrm{CHO}$ cells also demonstrated cytoplasmic localization of $\beta 3$ in $\alpha \mathrm{IIb} / \beta 3$ (p.T720del)-expressing CHO cells (Fig 3C). In platelets, the majority of $\beta 3$ exists as $\alpha \mathrm{IIb} \beta 3$, and the total expression level of $\beta 3$ is considered to represent the total expression level of $\alpha \operatorname{IIb} \beta 3[27,36]$. Physiologically, $\alpha \operatorname{IIb} \beta 3$ is retained not only on the platelet surface membrane but also in the cytoplasmic pool on the actin cytoskeleton or on the membrane of $\alpha$-granules [11,37]. It is also known that activated $\alpha \operatorname{IIb} \beta 3$ preferentially internalizes in normal platelets as a mechanism for downregulating adhesiveness of activated platelets in the circulation $[38,39]$. Considering this mechanism, the localization change in our patients would be due to the internalization of spontaneously activated $\alpha \operatorname{IIb} \beta 3$ (Fig 4). 
We found a novel heterozygous ITGB3 p.T720del variant that is responsible for autosomal dominant

congenital macrothrombocytopenia with abnormal $\alpha \operatorname{IIb} \beta 3$ localization and aggregation dysfunction of platelets. Although ITGA2B and ITGB3 are mutated molecules in GT, submembranous variant forms a distinct clinical entity that is characterized by autosomal dominant macrothrombosytopenia with aggregation dysfunction. Clinically, this disease is even rarer than GT, but it is important for it to be known widely by physicians in the field. Each congenital thrombocytopenia should be correctly diagnosed to avoid unnecessary administration of corticosteroids under diagnosis as immune thrombocytopenia.

\section{Compliance with ethical standards}

All procedures performed in studies involving human participants were in accordance with the ethical standards of the institutional research committee and with the 1964 Helsinki Declaration and its later amendments. Informed consent was obtained from all patients for being included in the study.

\section{Figure legends}

Fig 1.

(A) The family pedigree shows macrothrombocytopenic family members (filled) and non-affected family members (open). Circles and squares mean female and male, respectively. 
(B) Peripheral blood smear of the patient (i2) stained with May-Giemsa. The arrows indicate giant platelets.

(C) Results of platelet aggregation tests in response to ADP (Black, $1.0 \mu \mathrm{M}$, Red, $10.0 \mu \mathrm{M}$ ), collagen (Green, $2.0 \mu \mathrm{g} / \mathrm{ml}$, Blue, $5.0 \mu \mathrm{g} / \mathrm{ml})$, and ristocetin $(1.5 \mathrm{mg} / \mathrm{ml})$ stimuli in platelet-rich plasma from a patient (ii3).

(D) Genomic DNA was amplified by polymerase chain reaction and sequenced. A 3-base-pair deletion (c.2236_2238delACC) was found as a heterozygous variant. One threonine (T720) highlighted in red was expected to be lost in the affected family members.

(E) In silico modeling of $\alpha \mathrm{IIb}$ and $\beta 3$ interaction. The extracellular domain of $\alpha \mathrm{IIb}$ and $\beta 3$ was omitted. Wild-type $\alpha$ IIb $\beta 3$ complex has a close interaction between $\alpha$ IIb R995 and $\beta 3$ D723 at the submembrane region. $\beta 3$ p.D723H variant and $\beta 3$ p.T720del variant unclasp the membrane proximal interaction of $\alpha \mathrm{IIb}$ and $\beta 3$ cytoplasmic tails in resting conditions. The upper panel shows a horizontal view and the lower panel shows a view from cytoplasmic tails. Amino acid 723 position is aspartic acid (D) in the wild type but is substituted to histidine (H) in ITGB3 p.D723H and to arginine (R) in ITGB3 p.T720del.

Fig 2. Functional analyses of ITGB3 p.T720del variant using patient's platelets

(A) Western blotting was performed using platelet-rich plasma lysed with SDS lysis buffer. Protein loading was controlled by GAPDH. Although relative expression total amount of $\beta 3$ compared to 
GAPDH was decreased in an affected member reflecting thrombecytopenia, relative expression of $\beta 3$

eompared to $\beta 1$ tubulin was not decreased. The upper bar graph $\underline{\underline{s}}$ shows $\underline{s}$ relative expression of $\underline{\text { integrin }}$

$\beta 3$ compared to $\beta 1$-tubulin which is platelet specific protein. The lower bar graph showsand relative

expression of integrin $\beta 3$ compared to GAPDH which reflects both platelet and contaminated

$\underline{\text { mononuclear cells. Values of each samples were calibrated to that of control. Although relative }}$

expression of integrin $\beta 3$ compared to GAPDH was decreased in an affected member reflecting

thrombocytopenia, relative expression of integrin $\beta 3$ compared to $\beta 1$-tubulin was not decreased.

Results of immunoblotting are representative of 3 independent transfection experiments. $* P<0.05$.

N.S., not significant.

(B) Spontaneous binding of PAC-1 to $\alpha \mathrm{IIb} \beta 3$ in platelets of an affected family member (i2). Immediately after blood collection, platelets were incubated with PAC-1 in the presence or absence of $1 \mathrm{mM} \mathrm{Arg-}$ Gly-Asp-Ser (RGDS) mimetic antagonist and analyzed by flow cytometry. MFI ratio was estimated by dividing MFI of resting platelets by that of resting platelets incubated with RGDS.

(C) Activation index of $\alpha \mathrm{IIb} \beta 3$. Relative PAC-1 binding in resting platelets compared with maximal PAC1 binding in platelets stimulated with PMA is defined as activation index. Activation index in an affected family member (i2) was compared to that in the healthy volunteer.

(D) Activation of platelet $\alpha \mathrm{IIb} \beta 3$ in response to ADP in an affected family member (i2). Immediately after blood collection, platelets were incubated with PAC-1 in the presence or absence of $1 \mu \mathrm{M}$ ADP and 
analyzed by flow cytometry. MFI ratio was estimated by dividing MFI of platelets stimulated with

ADP by that of resting platelets.

(E) Lower expression levels of CD62P in an affected family member (i2) in response to ADP. Immediately after blood collection, platelets were incubated with CD62P in the presence or absence of $1 \mu \mathrm{M}$ ADP and analyzed by flow cytometry. MFI ratio was estimated by dividing MFI of platelets stimulated with ADP by that of resting platelets.

Fig 3. Results of transfection assay using cell lines

(A) Expressions levels of integrin $\alpha \mathrm{IIb}$ and $\beta 3$ in transiently transfected $293 \mathrm{~T}$ cells were shown by Western blotting. Whole cell lysates were immunoblotted.

(B) Tyrosine phosphorylation of FAK. Whole cell lysate was immunoblotted by anti-FAK (EP695Y) and anti-phospho-FAK (3283). Quantification of the phosphorylation state of FAK is also shown. The phosphorylation state of FAK was quantified as a density ratio of protein bands, pFAK/FAK. Values of each samples were calibrated to that of WT in an adhered condition. Results of immunoblotting are representative of 3 independent transfection experiments. $* P<0.05$ vs. WT in a suspension condition. FAK in $\alpha I I b / \beta 3$ (p.D723H)-expressing cells and that in $\alpha I I b / \beta 3$ (p.T720del)-expressing cells were highly phosphorylated with significant differences even under the suspension conditions.

(C) $\mathrm{CHO}$ cells transfected with $\alpha \mathrm{IIb} / \beta 3$ (p.D723H) and $\alpha \mathrm{IIb} / \beta 3$ (p.T720del) were seeded onto 
fibrinogen-coated coverslips. After 2-hour incubation at $37^{\circ} \mathrm{C}$, the cells were fixed and stained with AB2984 and Hoechst 33342 followed by staining with Alexa 594-conjugated secondary antibody. Rhomboid-like change, abnormal cytoplasmic protrusions, and membrane ruffling were observed by $\alpha \mathrm{IIb} \beta 3$ mutants. Arrowheads indicate abnormal cytoplasmic protrusions. Scale bar represents $15 \mu \mathrm{m}$. The panel on the right shows the intensity of the $\beta 3$ fluorescence signal along with $\mathrm{x}$ axis obtained by ImageJ (NIH, Bethesda, MD).

(D) One hundred cells were counted to calculate the percentage of cells with morphological change. Results are means plus or minus SD from 3 independent counts. $* P<0.01$.

(E) Whole cell lysate was collected 24 hours after transfection of ITGA2B and each ITGB3 expression vector with or without the FAK inhibitor Y15 (10 $\mu \mathrm{M}, 50 \mu \mathrm{M})$. Phosphorylation status of FAK was analyzed by Western blotting. The bar graph shows relative phosphorylation of FAK analyzed by pFAK/FAK. In each ITGB3 transfection, the value of FAK inhibitor-treated samples was calibrated to an FAK inhibitor untreated sample. Results are means plus or minus SD from 3 independent experiments. ${ }^{*} P<0.05$. N.S., not significant.

(F) Morphological changes of ITGA2B and ITGB3-transfected CHO cells were analyzed. One hundred cells were counted to calculate the percentage of cells with morphological change. Results are means plus or minus SD from 3 independent counts. $* P<0.05$. 
Fig 4. Molecular mechanisms of gain of function induced by ITGB3 p.T720del.

ITGB3 p.T720del unclasps the highly conserved membrane proximal complex of $\alpha \mathrm{IIb}$ and $\beta 3$ cytoplasmic tails and constitutes the extended form of the $\alpha \operatorname{IIb} \beta 3$ complex, leading to constitutive phosphorylation of

FAK. In megakaryocytes, tyrosine-phosphorylated FAK downregulates RhoA, which induces

dissociation of the actin-myosin IIA bridge and promotes abnormal actin remodeling. Formation of

proplatelets formation in premature megakaryocytes resulted in production of giant platelets and

thrombocytopenia. In platelets, activated $\alpha \operatorname{IIb} \beta 3$ is internalized and the surface expression of $\alpha \operatorname{IIb} \beta 3$

decreases, leading to aggregation dysfunction.

\section{References}

1. Balduini CL, Cattaneo M, Fabris F, Gresele P, Iolascon A, Pulcinelli FM, Savoia A, Italian Gruppo di Studio delle P (2003) Inherited thrombocytopenias: a proposed diagnostic algorithm from the Italian Gruppo di Studio delle Piastrine. Haematologica 88 (5):582-592 2. Kunishima S, Okuno Y, Yoshida K, Shiraishi Y, Sanada M, Muramatsu H, Chiba K, Tanaka H, Miyazaki K, Sakai M, Ohtake M, Kobayashi R, Iguchi A, Niimi G, Otsu M, Takahashi Y, Miyano S, Saito H, Kojima S, Ogawa S (2013) ACTN1 mutations cause congenital macrothrombocytopenia. Am J Hum Genet 92 (3):431-438. doi:10.1016/j.ajhg.2013.01.015

3. Kunishima S, Saito H (2006) Congenital macrothrombocytopenias. Blood Rev 20 (2):111121. doi:10.1016/j.blre.2005.08.001

4. Savoia A (2016) Molecular basis of inherited thrombocytopenias: an update. Curr Opin Hematol 23 (5):486-492. doi:10.1097/MOH.0000000000000269

5. Buitrago L, Rendon A, Liang Y, Simeoni I, Negri A, ThromboGenomics C, Filizola M, Ouwehand WH, Coller BS (2015) alphaIIbbeta3 variants defined by next-generation sequencing: predicting variants likely to cause Glanzmann thrombasthenia. Proc Natl Acad Sci U S A 112 (15):E1898-1907. doi:10.1073/pnas.1422238112

6. Ghevaert C, Salsmann A, Watkins NA, Schaffner-Reckinger E, Rankin A, Garner SF, 
Stephens J, Smith GA, Debili N, Vainchenker W, de Groot PG, Huntington JA, Laffan M, Kieffer N, Ouwehand WH (2008) A nonsynonymous SNP in the ITGB3 gene disrupts the conserved membrane-proximal cytoplasmic salt bridge in the alphaIIbbeta3 integrin and cosegregates dominantly with abnormal proplatelet formation and macrothrombocytopenia. Blood 111 (7):3407-3414. doi:10.1182/blood-2007-09-112615

7. Hardisty R, Pidard D, Cox A, Nokes T, Legrand C, Bouillot C, Pannocchia A, Heilmann E, Hourdille P, Bellucci S, et al. (1992) A defect of platelet aggregation associated with an abnormal distribution of glycoprotein IIb-IIIa complexes within the platelet: the cause of a lifelong bleeding disorder. Blood 80 (3):696-708

8. Jayo A, Conde I, Lastres P, Martinez C, Rivera J, Vicente V, Gonzalez-Manchon C (2010) L718P mutation in the membrane-proximal cytoplasmic tail of beta 3 promotes abnormal alpha IIb beta 3 clustering and lipid microdomain coalescence, and associates with a thrombasthenia-like phenotype. Haematologica $95 \quad$ (7):1158-1166. doi:10.3324/haematol.2009.018572

9. Kashiwagi H, Kunishima S, Kiyomizu K, Amano Y, Shimada H, Morishita M, Kanakura Y, Tomiyama Y (2013) Demonstration of novel gain-of-function mutations of alphaIlbbeta3: association with macrothrombocytopenia and glanzmann thrombasthenia-like phenotype. Mol Genet Genomic Med 1 (2):77-86. doi:10.1002/mgg3.9

10. Kunishima S, Kashiwagi H, Otsu M, Takayama N, Eto K, Onodera M, Miyajima Y, Takamatsu Y, Suzumiya J, Matsubara K, Tomiyama Y, Saito H (2011) Heterozygous ITGA2B R995W mutation inducing constitutive activation of the alphaIIbbeta3 receptor affects proplatelet formation and causes congenital macrothrombocytopenia. Blood 117 (20):54795484. doi:10.1182/blood-2010-12-323691

11. Nurden P, Bordet J, Pillois X, Nurden AT (2017) An intracytoplasmic 83 Leu718 deletion in a patient with a novel platelet phenotype. Blood Advances 1 (8):494-499

12. Peyruchaud O, Nurden AT, Milet S, Macchi L, Pannochia A, Bray PF, Kieffer N, Bourre F (1998) R to Q amino acid substitution in the GFFKR sequence of the cytoplasmic domain of the integrin IIb subunit in a patient with a Glanzmann's thrombasthenia-like syndrome. Blood 92 (11):4178-4187

13. Larson MK, Watson SP (2006) Regulation of proplatelet formation and platelet release by integrin alpha IIb beta3. Blood 108 (5):1509-1514. doi:10.1182/blood-2005-11-011957

14. Kasirer-Friede A, Kahn ML, Shattil SJ (2007) Platelet integrins and immunoreceptors. Immunol Rev 218:247-264. doi:10.1111/j.1600-065X.2007.00532.x

15. Bury L, Malara A, Gresele P, Balduini A (2012) Outside-in signalling generated by a constitutively activated integrin alphaIIbbeta 3 impairs proplatelet formation in human megakaryocytes. PLoS One 7 (4):e34449. doi:10.1371/journal.pone.0034449 
16. Biasini M, Bienert S, Waterhouse A, Arnold K, Studer G, Schmidt T, Kiefer F, Gallo Cassarino T, Bertoni M, Bordoli L, Schwede T (2014) SWISS-MODEL: modelling protein tertiary and quaternary structure using evolutionary information. Nucleic Acids Res 42 (Web Server issue):W252-258. doi:10.1093/nar/gku340

17. Wang Y, Geer LY, Chappey C, Kans JA, Bryant SH (2000) Cn3D: sequence and structure views for Entrez. Trends Biochem Sci 25 (6):300-302

18. Shattil SJ, Cunningham M, Hoxie JA (1987) Detection of activated platelets in whole blood using activation-dependent monoclonal antibodies and flow cytometry. Blood 70 (1):307-315

19. Kunishima S, Kobayashi R, Itoh TJ, Hamaguchi M, Saito H (2009) Mutation of the beta1tubulin gene associated with congenital macrothrombocytopenia affecting microtubule assembly. Blood 113 (2):458-461. doi:10.1182/blood-2008-06-162610

20. de Virgilio M, Kiosses WB, Shattil SJ (2004) Proximal, selective, and dynamic interactions between integrin alphaIIbbeta3 and protein tyrosine kinases in living cells. J Cell Biol 165 (3):305-311. doi:10.1083/jcb.200402064

21. Watson SP, Auger JM, McCarty OJ, Pearce AC (2005) GPVI and integrin alphaIIb beta3 signaling in platelets. J Thromb Haemost 3 (8):1752-1762. doi:10.1111/j.15387836.2005.01429.x

22. Legate KR, Wickstrom SA, Fassler R (2009) Genetic and cell biological analysis of integrin outside-in signaling. Genes Dev 23 (4):397-418. doi:10.1101/gad.1758709

23. Golubovskaya VM, Nyberg C, Zheng M, Kweh F, Magis A, Ostrov D, Cance WG (2008) A small molecule inhibitor, 1,2,4,5-benzenetetraamine tetrahydrochloride, targeting the y397 site of focal adhesion kinase decreases tumor growth. J Med Chem 51 (23):7405-7416. doi:10.1021/jm800483v

24. Nurden AT, Fiore M, Nurden P, Pillois X (2011) Glanzmann thrombasthenia: a review of ITGA2B and ITGB3 defects with emphasis on variants, phenotypic variability, and mouse models. Blood 118 (23):5996-6005. doi:10.1182/blood-2011-07-365635

25. Dorsam RT, Kunapuli SP (2004) Central role of the P2Y12 receptor in platelet activation. J Clin Invest 113 (3):340-345. doi:10.1172/JCI20986

26. Hirata T, Ushikubi F, Kakizuka A, Okuma M, Narumiya S (1996) Two thromboxane A2 receptor isoforms in human platelets. Opposite coupling to adenylyl cyclase with different sensitivity to Arg60 to Leu mutation. J Clin Invest 97 (4):949-956. doi:10.1172/JCI118518 27. Lefkovits J, Plow EF, Topol EJ (1995) Platelet glycoprotein IIb/IIIa receptors in $\begin{array}{llllll}\text { cardiovascular medicine. N } & \text { Nngl J } & \text { Med } & 332 & \text { (23):1553-1559. }\end{array}$ doi:10.1056/NEJM199506083322306

28. Springer TA, Dustin ML (2012) Integrin inside-out signaling and the immunological 
synapse. Curr Opin Cell Biol 24 (1):107-115. doi:10.1016/j.ceb.2011.10.004

29. Bennett JS (2005) Structure and function of the platelet integrin alphaIIbbeta3. J Clin Invest 115 (12):3363-3369. doi:10.1172/JCI26989

30. Flevaris P, Stojanovic A, Gong H, Chishti A, Welch E, Du X (2007) A molecular switch that controls cell spreading and retraction. J Cell Biol 179 (3):553-565. doi:10.1083/jcb.200703185

31. Kobayashi Y, Matsui H, Kanai A, Tsumura M, Okada S, Miki M, Nakamura K, Kunishima S, Inaba T, Kobayashi M (2013) Identification of the integrin beta3 L718P mutation in a pedigree with autosomal dominant thrombocytopenia with anisocytosis. Br J Haematol 160 (4):521-529. doi:10.1111/bjh.12160

32. Radley JM, Scurfield G (1980) The mechanism of platelet release. Blood 56 (6):996-999

33. Chang Y, Aurade F, Larbret F, Zhang Y, Le Couedic JP, Momeux L, Larghero J, Bertoglio J, Louache F, Cramer E, Vainchenker W, Debili N (2007) Proplatelet formation is regulated by the Rho/ROCK pathway. Blood 109 (10):4229-4236. doi:10.1182/blood-2006-04-020024

34. Chen Z, Naveiras O, Balduini A, Mammoto A, Conti MA, Adelstein RS, Ingber D, Daley GQ, Shivdasani RA (2007) The May-Hegglin anomaly gene MYH9 is a negative regulator of platelet biogenesis modulated by the Rho-ROCK pathway. Blood 110 (1):171-179. doi:10.1182/blood-2007-02-071589

35. Schaffner-Reckinger E, Salsmann A, Debili N, Bellis J, De Mey J, Vainchenker W, Ouwehand WH, Kieffer N (2009) Overexpression of the partially activated alpha(IIb)beta3D723H integrin salt bridge mutant downregulates RhoA activity and induces microtubule-dependent proplatelet-like extensions in Chinese hamster ovary cells. J Thromb Haemost 7 (7):1207-1217. doi:10.1111/j.1538-7836.2009.03494.x

36. Nieswandt B, Varga-Szabo D, Elvers M (2009) Integrins in platelet activation. J Thromb Haemost 7 Suppl 1:206-209. doi:10.1111/j.1538-7836.2009.03370.x

37. Shin EK, Park H, Noh JY, Lim KM, Chung JH (2016) Platelet Shape Changes and Cytoskeleton Dynamics as Novel Therapeutic Targets for Anti-Thrombotic Drugs. Biomol Ther (Seoul). doi:10.4062/biomolther.2016.138

38. Wencel-Drake JD, Boudignon-Proudhon C, Dieter MG, Criss AB, Parise LV (1996) Internalization of bound fibrinogen modulates platelet aggregation. Blood 87 (2):602-612 39. Schober JM, Lam SC, Wencel-Drake JD (2003) Effect of cellular and receptor activation on the extent of integrin alphaIIbbeta3 internalization. J Thromb Haemost 1 (11):2404-2410 
Fig 1

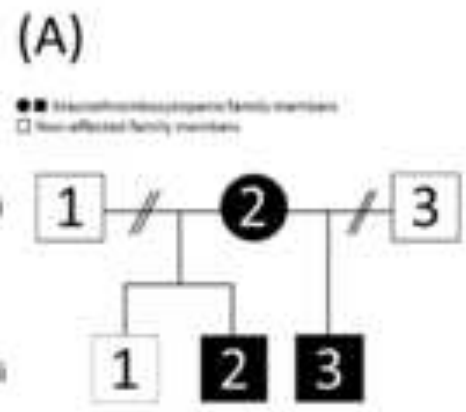

(C)

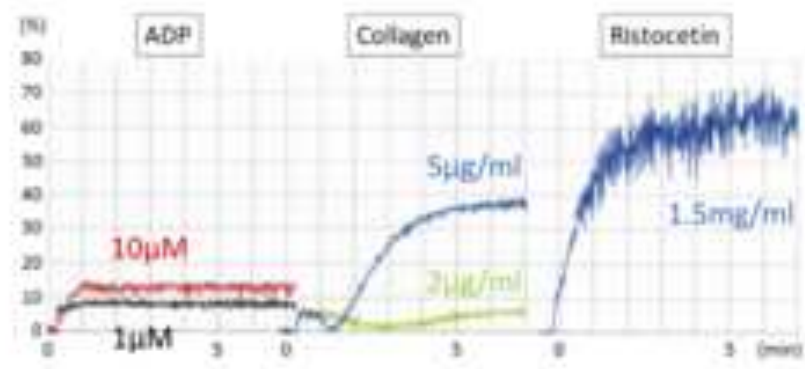

(B)

(D)

718719720721722

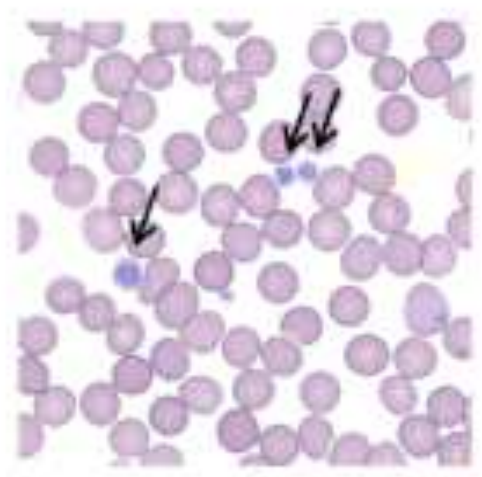

LTCu lle Thr lle His
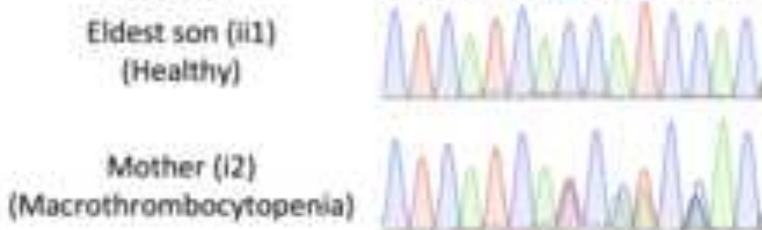

(Macrothrombocytopenia)

Second san (ii2)

(Macrothrombocytopenia)

Third son fii3)

(Macrothrombocytopenia)

Subcloned

Mutated aliele
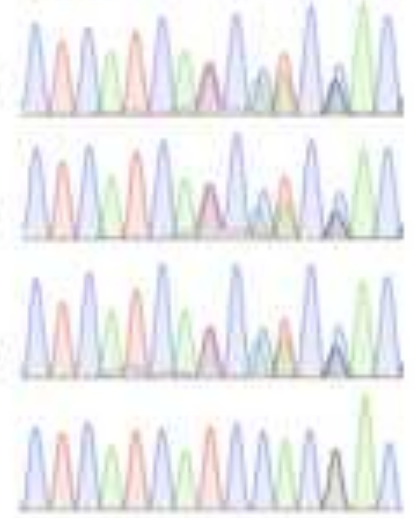

CTCATCATCCACGAC Leu lle lle His Asp

(E)

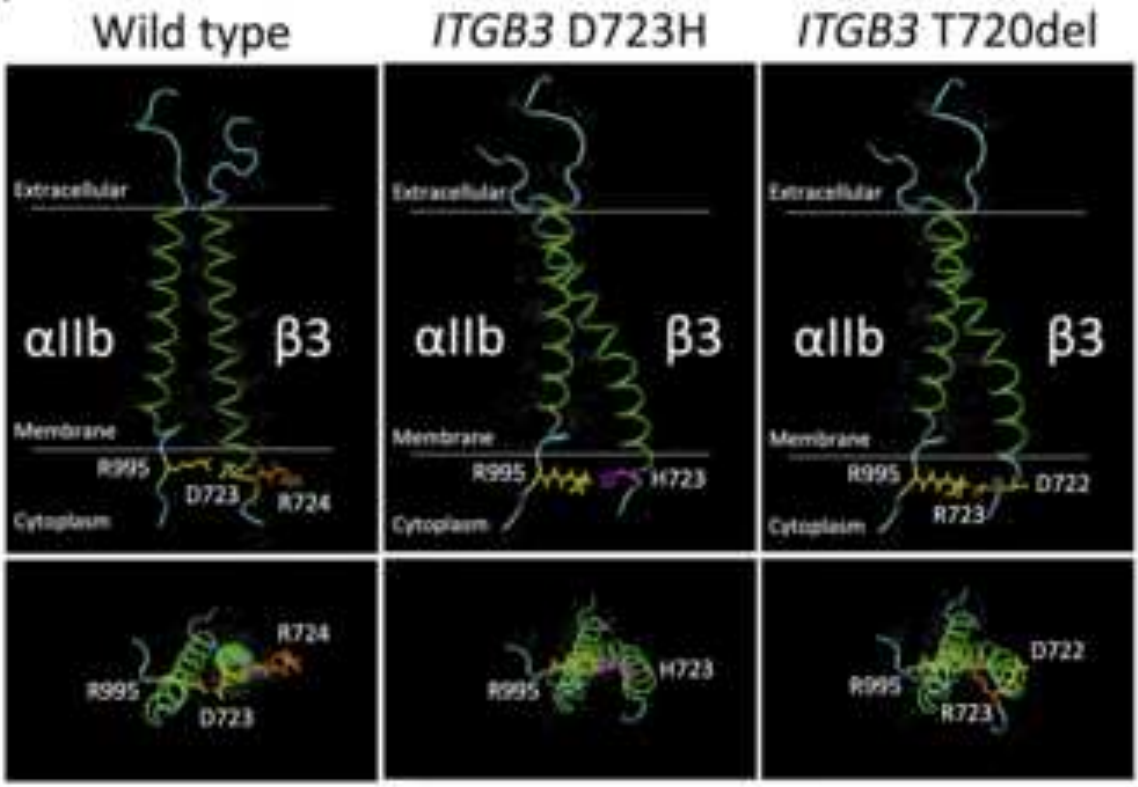


Fig 2

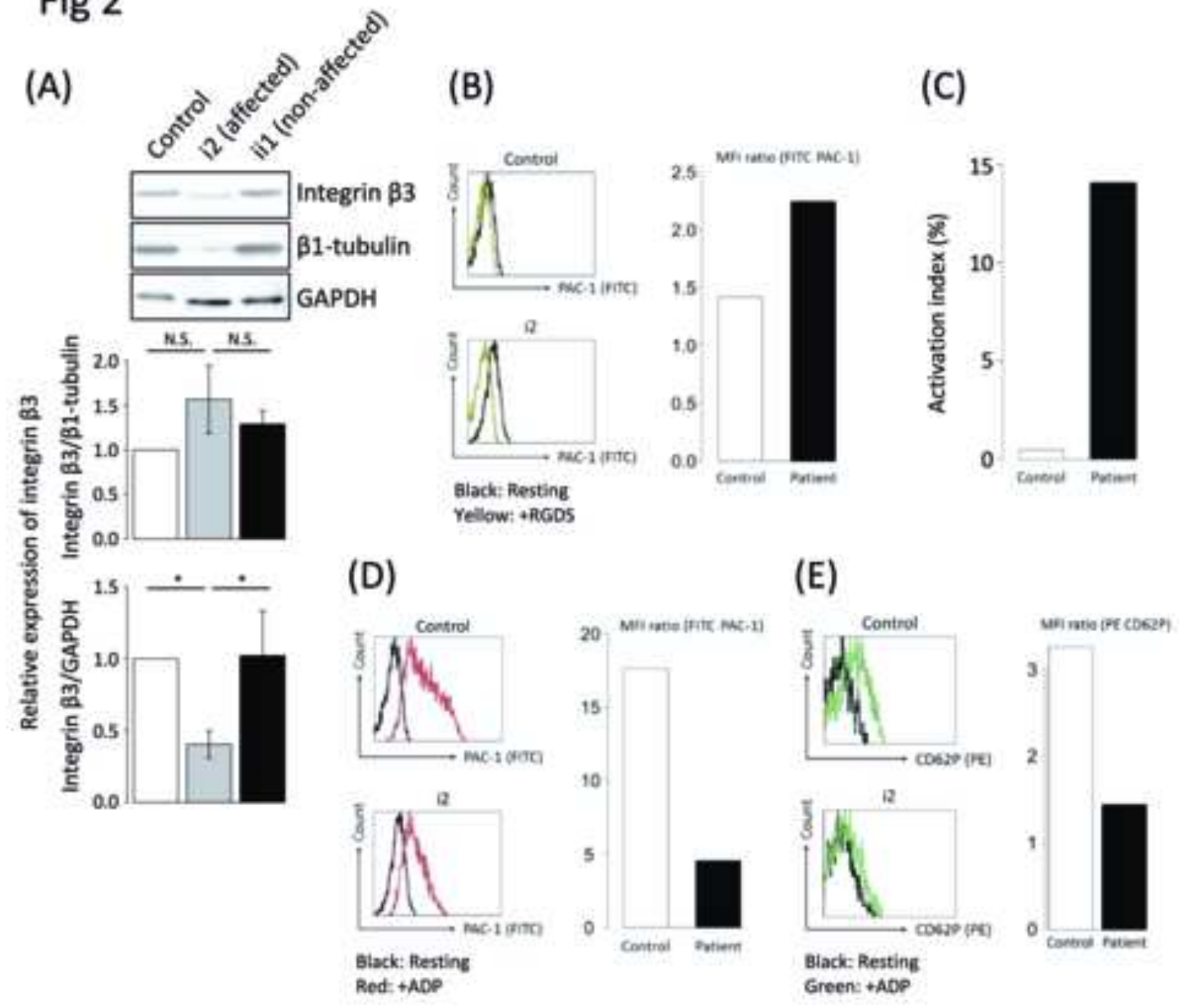


Fig 3

(A)

(C)
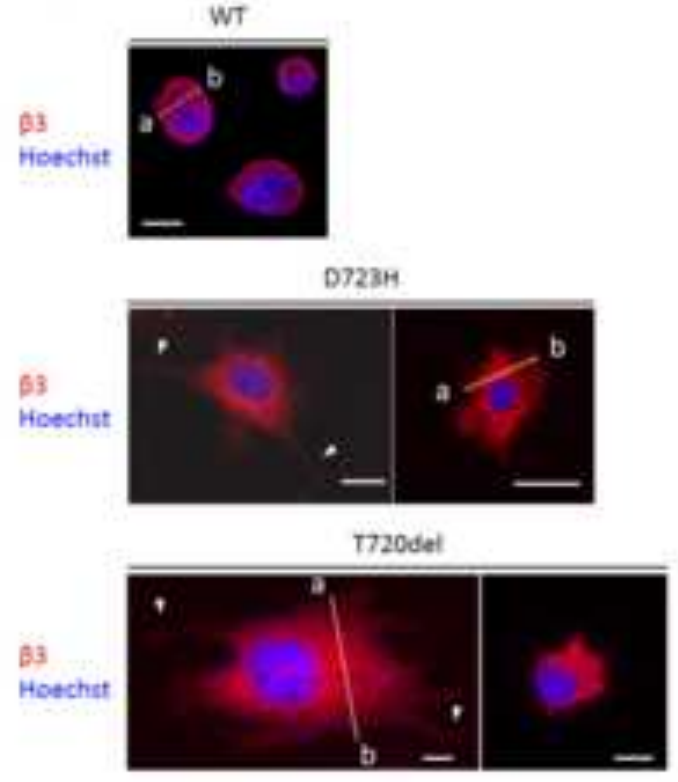

(E)

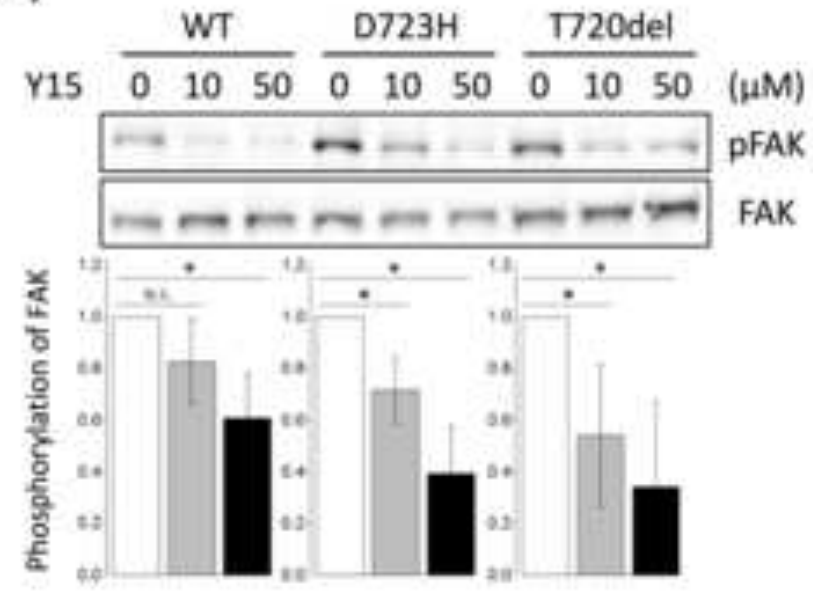

(B)

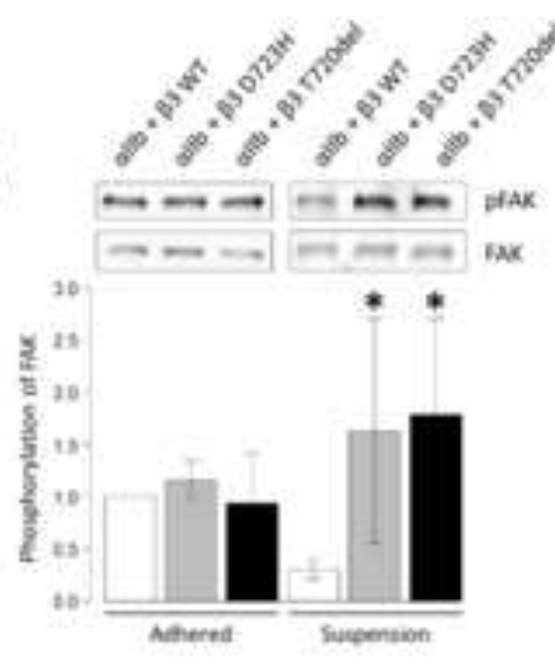

(D)
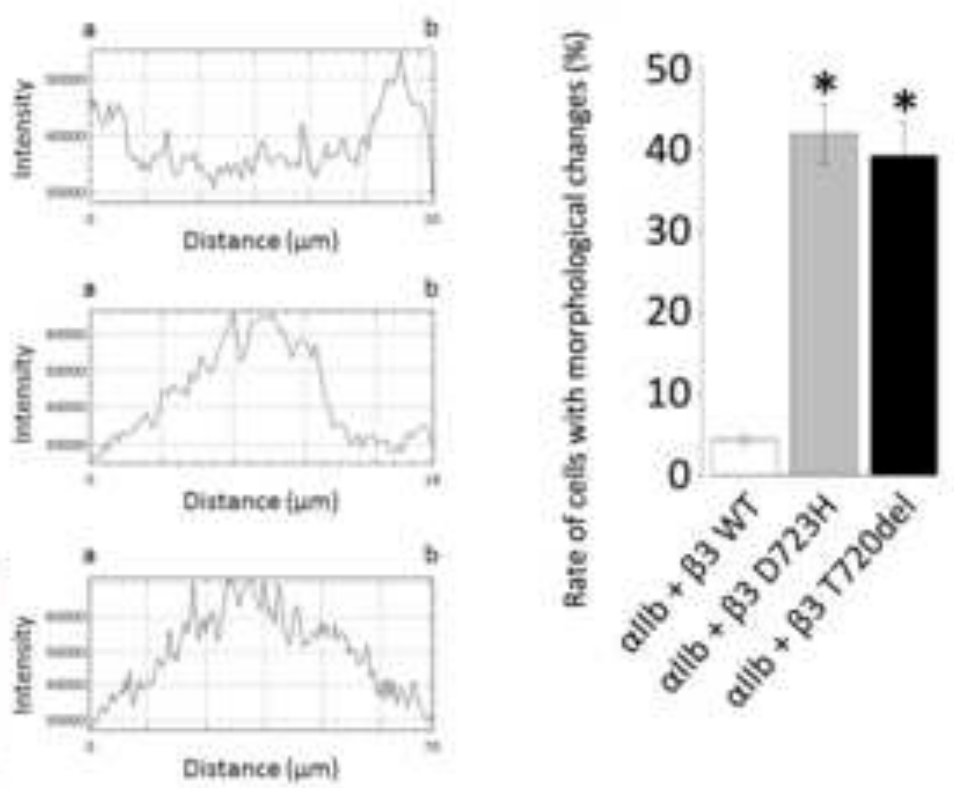

(F)

Y15 $\frac{W T}{01050} \frac{D 723 H}{01050} \frac{\text { T720del }}{01050 \quad(\mu M)}$

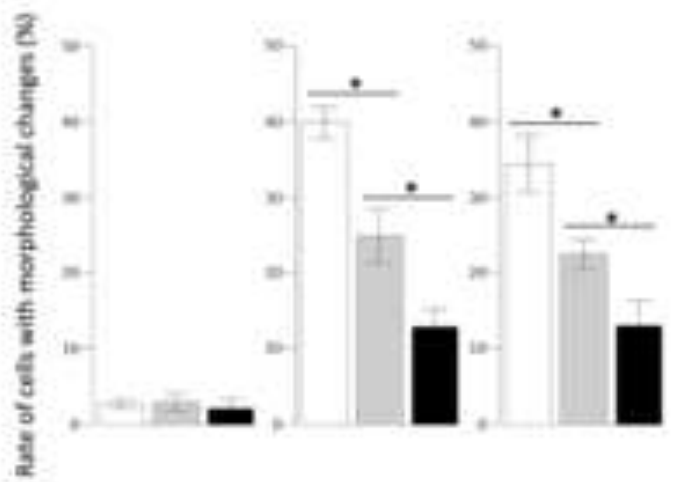


Fig 4

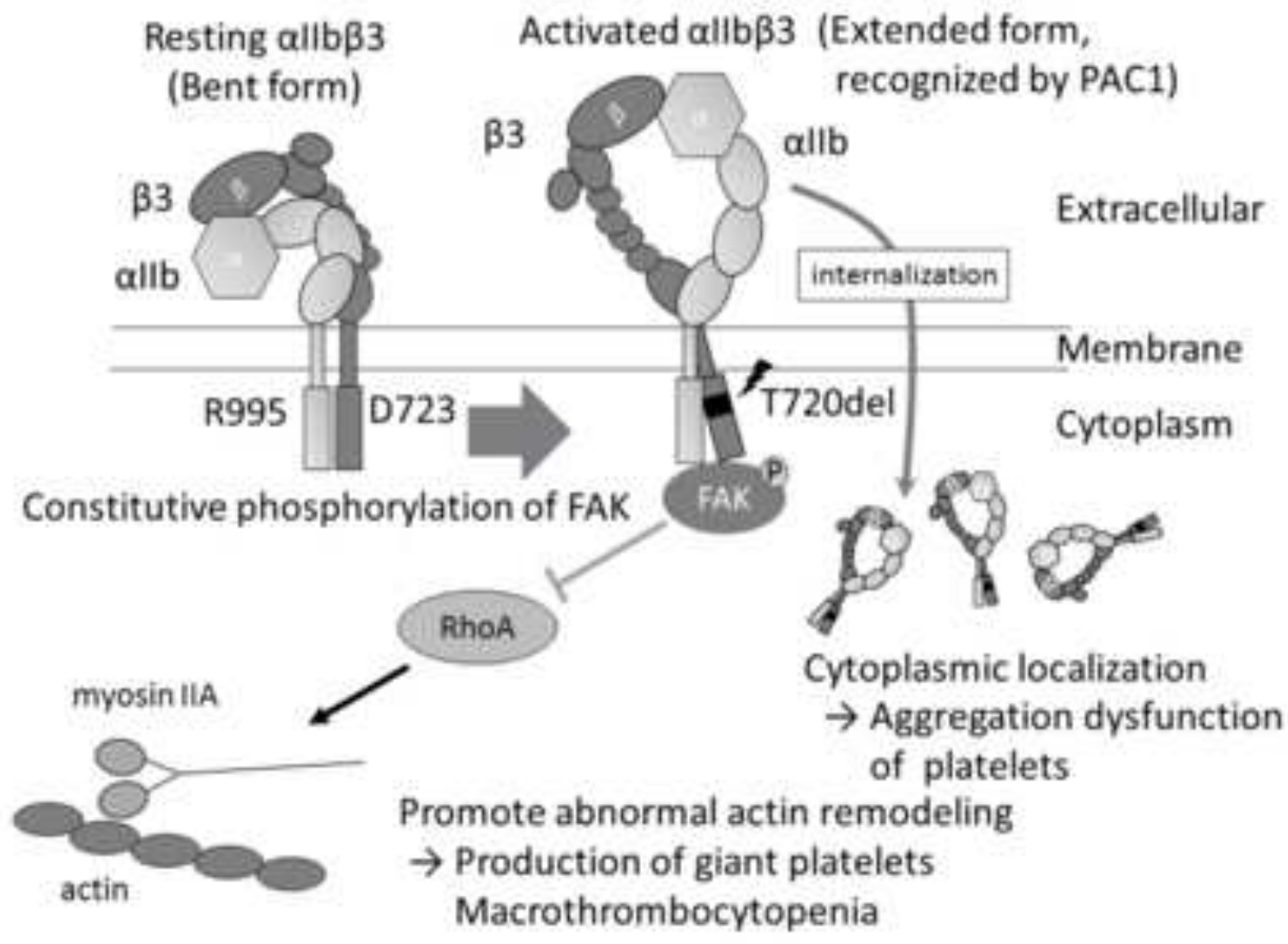


Table 1. Characteristics of 3 affected members (i2, ii2, and ii3) and a non-affected member (ii1)

\begin{tabular}{|c|c|c|c|c|c|c|c|c|}
\hline \multirow{2}{*}{ Family member } & \multirow{2}{*}{ Sex } & \multirow{2}{*}{ Age (years) } & \multirow{2}{*}{$\begin{array}{l}\text { Platelet count } \\
\qquad\left(x 10^{9} / \mathrm{I}\right)\end{array}$} & \multirow{2}{*}{$\begin{array}{c}\text { MPV } \\
\text { (normal range } \\
7.0-11.0 \mathrm{fl} \text { ) }\end{array}$} & \multirow{2}{*}{$\begin{array}{c}\text { Duke bleeding } \\
\text { time } \\
\text { (normal range } \\
3.0-5.0 \mathrm{~min} \text {.) }\end{array}$} & \multicolumn{3}{|c|}{ Platelet aggregation (normal range) } \\
\hline & & & & & & $\begin{array}{l}\text { ADP }(70-90 \%) \\
(10 \mu \mathrm{M})\end{array}$ & $\begin{array}{l}\text { Collagen }(70-90 \%) \\
\qquad(2 \mu \mathrm{g} / \mathrm{ml})\end{array}$ & $\begin{array}{c}\text { Ristocetin (60-90\%) } \\
(1.5 \mathrm{mg} / \mathrm{ml})\end{array}$ \\
\hline i2 & $\mathrm{F}$ & 56 & 74 & $13.4 \mathrm{fl}$ & $5.3 \mathrm{~min}$. & $34 \%$ & $39 \%$ & $73 \%$ \\
\hline ii2 & M & 19 & 75 & $14.5 \mathrm{fl}$ & $4.0 \mathrm{~min}$. & $14 \%$ & $7 \%$ & $73 \%$ \\
\hline ii3 & M & 25 & 58 & ND & $5.0 \mathrm{~min}$. & $30 \%$ & $22 \%$ & $62 \%$ \\
\hline ii1 & $M$ & 28 & 227 & $10.0 \mathrm{fl}$ & NA & $84 \%$ & $90 \%$ & $106 \%$ \\
\hline
\end{tabular}

Notes: Significant results are shown in bold.

Abbreviations: MPV, Mean platelet volume; min, minutes; ND, not determined; NA, not available; ADP, adenosine diphosphate. 
Table 2. Surface expression relative to control platelets

\begin{tabular}{|c|c|c|c|c|c|c|c|c|c|c|c|c|}
\hline \multirow[b]{3}{*}{$\begin{array}{l}\text { Family } \\
\text { member }\end{array}$} & \multicolumn{12}{|c|}{ Surface expression relative to control platelets (\%) } \\
\hline & \multicolumn{4}{|c|}{ Resting } & \multicolumn{4}{|c|}{ ADP } & \multicolumn{4}{|c|}{ PMA } \\
\hline & aIlb & B3 & allbB3 & GPIba & allb & B3 & aIlbB3 & GPIba & allb & B3 & aIIbB3 & GPIba \\
\hline i2 & 40.8 & 43.1 & 41.1 & 137.3 & 21.6 & 38.0 & 35.8 & 149.0 & 40.8 & 37.9 & 43.0 & 148.5 \\
\hline ii1 & 111.9 & 119.5 & 107.3 & 88.7 & 111.9 & 129.7 & 156.3 & 93.1 & 85.3 & 81.2 & 87.7 & 100.9 \\
\hline
\end{tabular}

Abbreviations: ADP, adenosine diphosphate; PMA, phorbol-12-myristate-13-acetate. 
Table 3. Reported gain of function variants of $\alpha$ Ilb $\beta 3$ resulting in macrothrombocytopenia

\begin{tabular}{|c|c|c|c|c|c|c|c|c|c|c|c|c|}
\hline \multirow[b]{2}{*}{ Mutation } & \multicolumn{2}{|c|}{ Platelets characteristics } & \multirow[b]{2}{*}{$\begin{array}{l}\text { bleeding } \\
\text { tendency }\end{array}$} & \multicolumn{3}{|c|}{ Aggregation assay } & \multicolumn{3}{|c|}{ Flow cytometory } & \multicolumn{2}{|c|}{ Functional assay } & \multirow[b]{2}{*}{ Reference } \\
\hline & $\begin{array}{l}\text { Platelet count } \\
\qquad\left(\times 10^{\circ} / L\right)\end{array}$ & MPV & & ADP & Collagen & Ristocetin & $\begin{array}{c}\text { allbB3 } \\
\text { expression } \\
\text { on } \\
\text { platelets }\end{array}$ & $\begin{array}{c}\text { allbB3 } \\
\text { activation } \\
\text { index } \\
\text { (platelets) }\end{array}$ & $\begin{array}{l}\text { allbb3 } \\
\text { activation } \\
\text { index } \\
\text { (transfected } \\
\text { cells) }\end{array}$ & $\begin{array}{c}\text { FAK } \\
\text { phosphorylation }\end{array}$ & $\begin{array}{l}\text { Morphological } \\
\text { changes in } \\
\text { transfected } \\
\text { cell (CHO) }\end{array}$ & \\
\hline $\begin{array}{l}\text { ITGB3 } \\
\text { T720del }\end{array}$ & $58-86$ & $12.8-14.5 \mathrm{fl}$ & no & $10-34 \%$ & $17-39 \%$ & $62-73 \%$ & $\begin{array}{c}\text { decreased } \\
(40 \%)\end{array}$ & 0.14 & NA & + & $\begin{array}{c}\text { long } \\
\text { protrusions, } \\
\text { rhomboid- } \\
\text { like, } \\
\text { membrane } \\
\text { ruffling }\end{array}$ & Our cases \\
\hline $\begin{array}{l}\text { ITGB3 } \\
\text { D723H }\end{array}$ & 80 & $17.0 \mathrm{fl}$ & no & normal & - & normal & decreased & NA & NA & NA & $\begin{array}{c}\text { long } \\
\text { protrusions }\end{array}$ & $\begin{array}{c}\text { Ghevaert et al, } \\
2008[6]\end{array}$ \\
\hline $\begin{array}{l}\text { ITGB3 } \\
\text { L718P }\end{array}$ & 127 & NA & $\begin{array}{l}\text { depends } \\
\text { on } \\
\text { individual }\end{array}$ & $10-20 \%$ & $10-20 \%$ & normal & $\begin{array}{c}\text { decreased } \\
(47 \%)\end{array}$ & NA & NA & - & $\begin{array}{l}\text { long } \\
\text { protrusions }\end{array}$ & $\begin{array}{l}\text { Jayo et al, } \\
2010[8]\end{array}$ \\
\hline $\begin{array}{l}\text { ITGB3 } \\
\text { L718P }\end{array}$ & $49-72$ & $9.8-10.9 \mathrm{fl}$ & mild & $15 \%$ & $10 \%$ & normal & $\begin{array}{c}\text { decreased } \\
(43-75 \%)\end{array}$ & NA & $0.23(\mathrm{CHO})$ & NA & $\begin{array}{c}\text { long } \\
\text { protrusions, } \\
\text { rhomboid- } \\
\text { like }\end{array}$ & $\begin{array}{c}\text { Kobayashi et al, } \\
2013[31]\end{array}$ \\
\hline $\begin{array}{l}\text { ITGB3 } \\
\text { L718del }\end{array}$ & $100-120$ & $11.5-12.5 \mathrm{fl}$ & $\begin{array}{l}\text { submcosal } \\
\text { bleeding }\end{array}$ & decreased & decreased & normal & decreased & NA & NA & NA & NA & $\begin{array}{l}\text { Nurden et al, } \\
2017[11]\end{array}$ \\
\hline $\begin{array}{l}\text { ITGA2B } \\
\text { F993del }\end{array}$ & $59-111$ & $11.9-12.8 \mathrm{fl}$ & no & NA & NA & NA & $\begin{array}{c}\text { decreased } \\
(74-82 \%)\end{array}$ & NA & $0.77(293 \mathrm{~T})$ & + & NA & $\begin{array}{c}\text { Kashiwagi et al, } \\
2013[9]\end{array}$ \\
\hline $\begin{array}{l}\text { ITGA2B } \\
\text { G991C }\end{array}$ & $22-109$ & $10.0-14.8 \mathrm{fl}$ & purpura & NA & NA & NA & $\begin{array}{c}\text { decreased } \\
(3-76 \%)\end{array}$ & 0.29 & $0.65(293 \mathrm{~T})$ & + & NA & $\begin{array}{c}\text { Kashiwagi et al, } \\
2013[9]\end{array}$ \\
\hline $\begin{array}{l}\text { ITGA2B } \\
\text { R995Q }\end{array}$ & $100-160$ & $10.3 \mathrm{fl}$ & $\begin{array}{l}\text { gingival } \\
\text { bleeding }\end{array}$ & decreased & decreased & NA & $\begin{array}{c}\text { decreased } \\
(15 \%)\end{array}$ & NA & $0.23(\mathrm{CHO})$ & NA & NA & $\begin{array}{l}\text { Peyruchaud et } \\
\text { al, } 1998[12]\end{array}$ \\
\hline $\begin{array}{l}\text { ITGA2B } \\
\text { R995W }\end{array}$ & $65-122$ & NA & $\begin{array}{l}\text { absent - } \\
\text { mild }\end{array}$ & $11-43 \%$ & $9-44 \%$ & $72-77 \%$ & $\begin{array}{l}\text { decreased } \\
(50-70 \%)\end{array}$ & NA & $0.19(293 \mathrm{~T})$ & + & $\begin{array}{c}\text { membrane } \\
\text { ruffling, } \\
\text { cytoplasmic } \\
\text { protrusion } \\
\text { with } \\
\text { bulbous tips }\end{array}$ & $\begin{array}{c}\text { Kunishima et al, } \\
2011[10]\end{array}$ \\
\hline
\end{tabular}

MPV, Mean platelet volume; NA, not available; ADP, adenosine diphosphate; FAK, Focal adhesion kinase; CHO, Chinese hamster ovary. 